\title{
2L OF POLYETHYLENE GLYCOL AS THE MAIN SMALL BOWEL CLEANSING REGIMEN COMPONENT PRIOR TO VIDEO CAPSULE ENDOSCOPY: INTERIM ANALYSIS
}

\author{
Aleksejs Derovs $^{1,2,3, \#}$, Jeḷena Derovaa ${ }^{1,3}$, Regina Kleina ${ }^{1}$, and Juris Pokrotnieks ${ }^{1,4}$ \\ ${ }^{1}$ Rīga Stradiṇš University, 16 Dzirciema Str., Rīga, LV-1007, LATVIA \\ ${ }^{2}$ Rīga East University Hospital, 2 Hipokrāta Str., Rīga, LV-1038, LATVIA \\ ${ }^{3}$ Latvian Maritime Medical Centre, 27 Patversmes Str., Rīga, LV-1005, LATVIA \\ ${ }^{4}$ Pauls Stradinšs Clinical University Hospital, Rīga, LATVIA \\ \# Corresponding author, aleksejs.derovs@gastroenterologs.Iv
}

Communicated by Aivars Lejnieks

\begin{abstract}
Capsule Enteroscopy (CE) is a fundamentally new method in diagnostic endoscopy. However, there are several factors influencing the quality of this procedure, including impermeable fluids, food remains etc. The aim of the study was to assess one of the most popular currently used bowel preparation methods and evaluate possible effects of various factors. 136 CE examinations were analysed. Each patient was prepared using 2 litres of polyethylene glycol (PEG) one day prior to examination. There was a special form filled in for each patient, which included relevant parameters (anamnesis, CE data etc.). Of 136 CE cases, 84 (61.8\%) were female patients and $52(38.2 \%)$ were male. The small bowel (SB) transit time in 112 patients varied from 39 to 502 minutes, but in 24 cases the capsule did not reach caecum. The degree of bowel cleanliness was as follows: very good - $30(22.1 \%)$ patients, satisfactory - $97(71.3 \%)$, and poor - 9 (6.6\%). A positive correlation was observed between the degree of SB cleanliness and the $S B$ transit time $(p=0.015)$. A longer SB transits time was associated with poor SB cleanliness. The results obtained in this study showed that the quality of SB cleanliness is affected by SB transit time. A relatively large percentage of cases rated as satisfactory bowel cleanliness and comparatively small percentage of bowel cleanliness cases rated as "very good" were observed when 2 litres of PEG were used prior to $C E$, indicating an important issues in preparation of the bowel prior to $C E$.
\end{abstract}

Key words: capsule endoscopy, transit time, bowel cleanliness, bowel preparation.

\section{INTRODUCTION}

Similarly to all other areas of medicine, there has been continuous development in the area of gastroenterology. In the last years, there have been thrilling achievements in the fields of gastroenterological disease screening, diagnostics, and treatment. Video Capsule Enteroscopy (CE) is a fundamentally new method in diagnostic endoscopy, which was gradually introduced to clinical practice starting from 2001. $\mathrm{CE}$ is completely different from all other conventional endoscopic methods in that it is a passive, little invasive, welltolerated method and it fills an information gap in cases where other methods are insufficient. The goal of using this method is diagnosis of pathologies of the small bowel (SB). The diagnostic modalities used until now for examining this part of gastrointestinal system are both very troublesome for the patient and technically difficult for the operator (conventional enteroscopy) or are uninformative (radiologic studies with contrast), (Costamagna et al., 2002).

Despite the fact that capsule endoscopy has proved to be a valuable diagnostic tool, there are several factors influencing the quality of this procedure, including:

- the presence of black or impermeable fluids, food remains, bile secretion, air bubbles or mucous in the lumen which can hinder or delay the diagnosis due to the incomplete visualisation of the intestinal mucosa;

- slow gastric emptying or small-bowel transit delaying the movement of the capsule to the caecum during the nor- 
mal duration of the capsule battery life (approximately 8 hours). According to the available statistics in the worldwide literature, this may occur in $17-25 \%$ of cases (Rondonotti et al., 2004; Rondonotti et al., 2005).

Consequently, it is crucial to establish the correct regimen of bowel cleansing before $\mathrm{CE}$, to avoid the presence of many substances in SB lumen, which may affect the sensitivity of this endoscopical method. Until now, there have been no reports for such trials in the CE field in Latvia or in the Baltic States.

The primary endpoint of this study was to evaluate the efficacy of using 2 litres of polyethylene glycol as a SB cleansing regimen prior to $\mathrm{CE}$ in patients with different $\mathrm{CE}$ diagnoses, based on our personal experience working with three of commercially available capsule endoscopy systems used in the world. Secondary endpoints of this study were:

- to evaluate possible additional impact factors (such as patients' age, sex or Body Mass Index (BMI)) on SB cleansing level;

- to evaluate SB cleansing level in different parts of SB if the SB cleanliness was imperfect.

\section{MATERIALS AND METHODS}

Study design. This was a multicentre study. Consecutive patients undergoing a CE were prospectively studied. There was no preference for certain capsule endoscopy system and the patients were randomly divided into one of the CE systems. No age restrictions were applied. Patients over 18 years of age gave written informed consent. For patients younger than 18 years written informed consent from parents was required.

A complication was defined as any event that changed the health status of a patient negatively within 30 days after CE.

Patients. A total of $136 \mathrm{CE}$ cases were analysed. All patients who had undergone CE were either from Pauls Stradiņš Clinical University Hospital, Latvian Maritime Medicine Centre or Children's Clinical University Hospital. The indications for the CE diagnostics at the time when the trial was started were according to the European Society of Gastrointestinal Endoscopy Guidelines (Rey et al., 2006). The following exclusion criteria for examination were used:

- high risk of capsule retention (patients with obstruction previously confirmed by X-ray or other specific examination, diagnosed stenosis, adhesions and/or diverticulum in the gastro-intestinal tract, which could impact the movement of the capsule endoscope);

- patients who could not have abdominal surgery;

- pregnant patients;

- patients with serious impairment of gastro-intestinal transi;
- patients with impaired swallowing, because the endoscopy capsule could accidentally enter the trachea.

Prior to CE examination, all patients had undergone upper and lower endoscopy, as well as various radiologic studies (including angiography, CT, MRI, irigoscopy, intestinal transit studies) with no pathology established. BMI (weight $(\mathrm{kg})$ divided by height squared $\left(\mathrm{m}^{2}\right)$ ) was calculated for each patient.

CE procedure. We used three capsule endoscopy systems: Olympus Endocapsule, Given Imaging PillCam and OMOM Capsule Endoscope equipped with standard software applications for these systems. Pictures were taken at a rate of $2 \mathrm{fps}$. All patients underwent a bowel preparation that consisted of transparent fluid intake (at will) 24 hours prior to examinations, and ingestion of 2 litres of polyethylene glycol-based electrolyte solution (PEG) 12 hours prior to the examination. All patients fasted 12 hours prior to VCE (Niv et al., 2004; Lewis et al., 2005; Melmed et al., 2005; Delvaux et al., 2007; Mergener et al., 2007; Pons Beltran et al., 2008).

The assessment of the intestinal cleanliness was made using the following: very good (no bubbles, no fluid in the lumen); satisfactory (bubbles and fluid were partly hindering visualisation of the SB mucosa); poor (due to the bubbles and fluid solitary areas of the SB mucosa could not be visualised).

Quality assessment. Two independent interpreters performed the analysis of each patient's VCE recording. The internationally recognised definitions and criteria were used for interpretation (Korman, 2005; Mergener et al., 2007; Gralnek et al., 2008). The research was carried out in accordance with the Helsinki Declaration and was approved by the local Ethical Committee.

Statistical analysis. This study was originally designed to investigate correlation between patients' age, sex or BMI on bowel cleaning. For this purpose, a bivariate two-tailed correlation was used. Kendall's tau_b and Spearman's rho correlation coefficients were used. There was a special form filled in for each patient with more than three hundred parameters including patient history data, results of performed laboratory and other studies, as well as all CE data. Subsequently the data were entered into a database.

Data were analysed using SPSS version 16.0 for windows. Any $p$-values given are two-sided and subject to a local significance level of $5 \%$.

\section{RESULTS}

Patient characteristics. 136 patient cases were entered into the database during the period from July 2006 to June 2010. Of these, $84(61.8 \%)$ were female patients and $52(38.2 \%)$ were male. The youngest patient was 13 years old and the oldest was 79 (mean age $43.6 \pm 17.5$ ). The major indication for CE was Crohn's disease $(n=50)$, followed by obscure 
Table 1. Indication for $\mathrm{CE}, \mathrm{n}(\%)$

$\begin{array}{ll}\text { Crohn's disease } & 50(36.8 \%) \\ \text { Obscure gastrointestinal bleeding } & 28(20.6 \%) \\ \text { Chronic anaemia } & 20(14.7 \%) \\ \text { Chronic abdominal pain } & 23(16.9 \%) \\ \text { Small bowel tumour } & 8(5.9 \%) \\ \text { Celiac disease } & 7(5.1 \%)\end{array}$

gastrointestinal bleeding $(\mathrm{n}=28)$, chronic anaemia, suspected celiac disease, suspected small bowel tumour and chronic abdominal pain (see Table 1).

CE procedure. No technical difficulties were encountered with the introduction of the CE systems. Thirty two (23.5\%) examinations were performed using Given Imaging PillCam, $32(23.5 \%)$ examinations using an Olympus Endocapsule, and $72(52.9 \%)$ examinations using an OMOM Capsule Endoscope. No statistically significant difference was found between the capsule endoscopy systems. In each case, approximately 50000 images were taken. The analysis of the data for each interpreter took 1-2 hours depending on the pathology and degree of intestinal cleanliness. The length of the time period of capsule endoscopy varied from 377 to 631 minutes (mean $493.0 \pm 38.6$ minutes). The stomach transit time was from 2 minutes to 441 minutes (mean $46.5 \pm 52.4$ minutes). The small intestine was completely examined, i.e. the capsule reached the caecum in 102 $(75.0 \%)$ of patients, but in 24 patients the capsule did not reach the caecum, and thus the examination of the small intestine was incomplete. The transit time through the small intestine in 112 patients varied from 39 to 502 minutes (mean $280.7 \pm 90.0$ minutes)

Findings. BMI was calculated for all patients (Melmed et al., 2005): in the $1^{\text {st }}$ group $(<18.50 \mathrm{BMI})$ there were 16 $(11.8 \%)$ patients, in the $2^{\text {nd }}$ group (18.50-24.99 BMI) there were $72(52.9 \%)$ patients, in the $3^{\text {rd }}$ group (25.00-29.99 BMI) there were 27 patients $(19.9 \%)$ and in the $4^{\text {th }}$ group (30.0 BMI) - 21 patients $(15.4 \%)$.

The degree of bowel cleanliness was as follows:

- very good - $30(22.1 \%)$ patients,

- satisfactory - 97 (71.3\%) patients,

- poor - $9(6.6 \%)$ patients.

The main established diagnoses, i.e. the principal findings, were as follows: Crohn's disease in 36 (26.5\%) cases, arteriovenous malformations (angiodysplasias) - 12 $(8.8 \%)$, erosive enteropathy - $31(22.8 \%)$, polyposis of the small intestine $-2(1.5 \%)$, non-steroidal anti-inflammatory drugs related injuries - $7(5.1 \%)$, celiac disease $9(6.6 \%)$, small intestine tumour - $6(4.4 \%)$, diverticulas $3(2.2 \%)$, parasites in the small intestine $-1(0.7 \%)$, diagnoses with small clinical impact (segmental enteropathy (26), multiple lymphangiectasias (1), multiple polyp-like mucosal elevations (1), and multiple phlebectasias (1) - 29 $(21.2 \%)$.
Using Kendall's tau_b and Spearman's rho correlation coefficients, a positive correlation was observed between the degree of small intestinal cleanliness and the small intestine transit time (for both coefficients probability $p=0.015$ ). Respectively, a longer small intestine transit time was associated with low level of small intestinal cleanliness.

We did not find statistical correlation between patient age, sex, BMI or capsule endoscope system and grade of bowel cleanliness.

Complications. In CE procedures included in this study, whilst complying with inclusion and exclusion criteria, no complications were reported within 30 days after CE. All patients tolerated the examination well and made no remarks of any side effects.

\section{DISCUSSION}

Capsule endoscopy is a rather new method for small intestine diagnostics, which has now found an established place in clinical practice. However, in general there are a relatively small number of performed procedures, consequentially resulting in a small number of scientific studies, and therefore, serious issues with respect to methodology.

Many clinicians have emphasised that a validated generally accepted scale for grading of SB cleaning is missing, despite of many tries to develop one (Ponte et al., 2016).

The total number of 136 cases analysed is small, but it should be taken into account that: 1) there is generally a small number of this type of examinations performed in other studies, 2) similar studies are often based on this number of patients, 3) this is an interim analysis and it is planned to analyse a greater number of patients who underwent CE.

The standard bowel preparation recommended by the capsule endoscope manufacturers is a clear liquid diet one day prior to video capsule endoscopy and 8-12 hours fasting prior to the commencement of the procedure (Melmed et al., 2005). On the other hand, as it has been seen in practice, if the practitioner is guided by these recommendations, he could face a number of problems, making the process of data interpretation and reaching diagnosis more difficult. Several published studies assess the usefulness of various additional bowel preparation medicines before the capsule endoscopy procedure (Song et al., 2016; Chen et al., 2017; Wu et al., 2019).

Studies tend to differ depending on the type of the bowel preparation (polyethylene glycol (PEG), sodium phosphate (NaP), Simethicone), time of taking the indicated agent, and number of patients. In the studies where NaP or PEG was used for the bowel preparation (Niv et al., 2004; Fireman et al., 2005; Niv et al., 2005; Adler et al., 2017), it was established that in these patients the visualisation of the small intestine was better than in patients with the standard bowel preparation. Another study (Albert et al., 2004), addressing the effect of Simethicone, found a positive effect of Sime- 
thicone on intestinal visualisation. Simethicone is a cleansing agent that tears up the gas bubbles, thus improving intestinal cleaning and visualisation of the intestinal mucosa.

There are three interesting prospective randomised studies focused on the efficacy of PEG used prior to capsule endoscopy. The authors used either 2 litres or 4 litres of PEG for patient preparation. The use of PEG prior to video capsule endoscopy significantly improved the visualisation of the intestinal lumen and mucosa, therefore improving the value of this diagnostic method (Viazis et al., 2004; Ben-Soussan et al., 2005; Dai et al., 2005). The results of yet one more randomised prospective controlled study showed that use of Simethicone $300 \mathrm{mg} 20$ minutes prior to video capsule enteroscopy reduced the number of air bubbles in the lumen (Ge et al., 2006). However, the dose of Simethicone used in this study was considerably large.

In 2007, a group of clinicians (Wei Wei et al., 2008) conducted a study comparing three patient groups: 1 litre PEG, 1 litre PEG and $300 \mathrm{mg}$ Simethicone and a control group receiving 1 litre of pure water only. The results of this study showed that any of the two given preparation methods in comparison to control group had statistically significant improvement on the visualisation of the distal ileal mucosa. In addition, the quality of the images was better in the group using either PEG or Simethicone.

A recent study performed by Wu et al. (2019) showed better visualization of SB using a regimen of 1L PEG 4 hours prior to $\mathrm{CE}$ as well as better tolerability of this regimen by the patients. Other study performed by Chen et al. (2017), showed good results after three days fasting and oral senna, combined with $20 \%$ mannitol and Simethicone prior to CE. According to the authors, this regimen especially improved visualisation in distal SB. In a study of 40 patients, better visualisation in the distal third of SB was obtained using a combination of sodium picosulfate, magnesium oxide and citric acid one hour after swallowing of a capsule endoscope (Adler et al., 2017).

Unfortunately, until now there have been no unified guidelines established describing the bowel preparation method prior to video capsule endoscopy. Based on the data derived from the worldwide scientific literature, the use of special agents for bowel preparation (PEG, NaP) results in a somewhat better visualisation of the small bowel mucosa in comparison to preparing the patient with a strict diet only. However, there are no specific guidelines yet developed that would allow determining the dosage of the agent, the time of starting the preparation of the patient, etc. We need to have more double-blind randomised studies in order to reach a consensus on these issues. Unfortunately, most of the studies now available are heterogeneous and mostly modest in quality.

Amongst our patients, very good bowel cleanliness degree was observed in $22.1 \%$, satisfactory in $71.3 \%$ and poor in $6.6 \%$ of the cases. Therefore, the intestinal wall was visualised perfectly only in one fourth of the patients. Evidently, this confirms that there are weaknesses in patients' bowel preparation methods available. Taking into account that these methods were adopted from the leading world clinics, it can be concluded that this problem is yet awaiting solutions.

Taking into account that we have analysed one method (2 litres of polyethylene glycol), we can judge on the efficacy of this method only. In patients with a poor degree of bowel cleanliness in the areas where there was an accumulation of bowel contents (no visualiation due to bubbles and fluids), differentiation of the topography was not possible. As a result of this, the examination of the small intestine was incomplete. Therefore, there is a chance that some areas with pathology were not visualised and thus the diagnosis could be incomplete. The poorly cleansed small bowel areas were mostly located distally. However, with difficulties, it was possible to differentiate the contours of the intestinal wall in patients with satisfactory bowel cleanliness (bubbles and fluid hindering visualisation). In these cases, the time for data interpretation was increased by approximately 30-40 minutes.

According to our experience, it can be concluded that the cleanliness of the bowel is significantly correlated to the transit time in the small bowel. If the small intestine transit time is shorter than 260 minutes, we can await a very good to satisfactory bowel cleanliness level. However, if the small bowel transit time is longer than 260 minutes, the bowel cleanliness level will be satisfactory to poor. Such a cleanliness level could hinder the visualisation of the small bowel mucosa. Therefore, if we suspect delayed small bowel transit in a certain patient, we should focus on bowel preparation before the capsule endoscopy to avoid poor intestinal cleanliness.

Prior to the commencement of this study there was a hypothesis that bowel cleanliness is predominantly influenced by the Crohn's disease, which is often characterised by a slower transit in small bowel and not infrequently — with capsule retention. We did not obtain results that could confirm this hypothesis and moreover we had paradoxical results, i.e. that patients with the Crohn's disease could achieve very good degree of bowel cleanliness in $25.0 \%$, satisfactory cleanliness in $69.4 \%$ and poor in $5.5 \%$ of cases.

The authors have worked with three leading manufacturers of endocapsules - Given Imaging with their product PillCam, Japanese Olympus with Endocapsule and Chinese Jinshang Science and Technics with OMOM. Currently the authors are the most experienced operators in the Baltic States working with different capsule endoscopy systems. On the other hand, the capsule systems used are quite similar and extremely dependent on the degree of bowel cleanliness.

\section{CONCLUSIONS}

The results obtained in this study showed that the quality of small bowel cleanliness is influenced by small bowel transit time. A relatively large percentage of satisfactory bowel 
cleanliness cases and a comparatively small percentage cases with bowel cleanliness rated as "very good" were obtained when 2 litres of polyethylene glycol were used as a bowel preparation method prior to CE, pointing out important issues in preparation of the bowel prior to capsule endoscopy.

\section{REFERENCES}

Adler, S. N., Farkash, S., Sompolinsky, Y., Gafanovich, I., Goldin, E., Bar-Gil Shitrit, A. (2017). A novel purgative protocol for capsule endoscopy of the small bowel produces better quality of visibility than 21 of PEG: Timing is of the essence. United Eur. Gastroenterol. J., 5 (4), 485-490.

Albert, J., Gobcl, C. M., Lesske, J., Lotterer, E., Nietsch, H., Fleig, W. E. (2004). Simethicone for small bowel preparation for capsule endoscopy: A systematic, single-blinded, controlled study. Gastrointest. Endosc., 4 (4), 487-491

Ben-Soussan, E., Savoye, G., Antonietti, M., Ramirez, S., Ducrotte, P., Lerebours, E. (2005). Is a 2-liler PEG preparation useful before capsule endoscopy? J. Clin. Gastroenterol., 39, 381-384.

Chen, H. B., Lian-Xiang, P., Yue, H., Chun, H., Shu-Ping, X., Rong-Pang, L., Xiao-Zong, W., Xiao-Lin, L. (2017). Randomized controlled trial of 3 days fasting and oral senna, combined with mannitol and simethicone, before capsule endoscopy. Medicine (Baltimore), 96 (43), e8322.

Costamagna, G., Shah, S. K., Riccioni, M. E., Foschia, F., Mutignani, M., Perri, V., Vecchioli, A., Brizi, M. G., Picciochi, A., Marano, P. (2002). A prospective trial comparing small bowel radiographs and videocapsule endoscopy for suspected small bowel disease. Gastroenterology, 123, 999-1005.

Dai, N., Gubler, C., Hengsteler, P., Meyenberger, C., Bauerfeind, P. (2005). Improved capsule endoscopy after bowel preparation. Gastrointest. Endosc., 61, 28-31.

Delvaux, M., Friedman, S., Keuchel, M., Hagenmüller, F., Weinstein, M., Cave, D., de Franchis, R., Gay, G., Korman, L. Y. (2007). Structured terminology for capsule endoscopy: Results of retrospective testing and validation in 766 small-bowel investigations. Endoscopy, 37 (10), 945-950.

Fireman, Z., Paz, D., Kopelman, Y. (2005). Capsule endoscopy: Improving transit time and image view. World J. Gastroenterol., 11 (37), 5863-5966.

Ge, Z. Z., Chen, H. Y., Gao, Y. J., Hu, Y. B., Xiao, S. D. (2006). The role of simeticone in small-bowel preparation for capsule endoscopy. Endoscopy, 38 (8), 836-840.

Gralnek, I. M., Defranchis, R., Seidman, E., Leighton, J. A., Legnani, P., Lewis, B. S. (2008). Development of a Capsule Endoscopy Scoring Index for Small Bowel Mucosal Inflammatory Change. Aliment Pharmacol. Ther., 27 (2), 146-154.

Korman, L. Y., Delvaux, M., Gay, G., Hagenmuller, F., Keuchel, M., Friedman, S., Weinstein, M., Shetzline, M., Cave, D., de Franchis, E. (2005). Capsule Endoscopy Structured Terminology (CEST): Proposal of a stan- dardized and structured terminology for reporting capsule endoscopy procedures. Endoscopy, 37 (10), 951-959.

Lewis, B. S., Eisen, G. M., Friedman, S. (2005). A pooled analysis to evaluate results of capsule endoscopy trials. Endoscopy, 37 (10), 960-965.

Melmed, G. Y., Lo, S. K. (2005). Capsule endoscopy: Practical applications. Clin. Gastroenterol. Hepatol., 3, 411-422.

Mergener, K., Ponchon, T., Gralnek, I., Pennazio, M., Gay, G., Selby, W., Seidman, E. G., Cellier, C., Murray, J., de Franchis, R., Rosch, T., Lewis, B. S. (2007). Literature review and recommendations for clinical application of small-bowel capsule endoscopy, based on a panel discussion by international experts. Consensus statements for small-bowel capsule endoscopy, 2006/2007. Endoscopy, 39 (10), 895-909.

Niv, Y., Niv, G. (2004). Capsule endoscopy: Role of bowel preparation successful visualization. Scand. J. Gastroenterol., 39, 1005-1009.

Niv, Y., Niv, G., Wiser, K., Demarco, D. C. (2005). Capsule endoscopycomparison of two strategies of bowel preparation. Aliment Pharmacol. Ther., 22, 957-962.

Pons Beltran, V., Carretero, C., Gonzalez-Suarez, B., et al. (2008). Intestinal preparation prior to capsule endoscopy administration. World J. Gastroenterol., 14 (37), 5773-5775.

Ponte, A., Pinho, R., Rodrigues, A., Carvalho, J. (2016). Review of small-bowel cleansing scales in capsule endoscopy: A panoply of choices. World J. Gastrointest. Endosc., 8 (17), 600-609.

Rey, J. F., Ladas, S., Alhassani, A., Kuznetsov, K. (2006). Video capsule endoscopy: Update to guidelines (May 2006). Endoscopy, 38, 1047-1053.

Rondonotti, E., Abbiati, C., Signorelli, C., et al. (2004). Reaching the ileocecal valve during capsule enteroscopy in independent both from intestinal preparation with laxatives and from the use of prokinetic drugs prior to the exam. Gastroenterology, 126, A461.

Rondonotti, E., Herrerias, J. M., Pennazio, M., Caunedo, A., MascarenasSaraiva, M., de Franchis, R. (2005). Complications, limitations and failures of capsule endoscopy: A review of 733 cases. Gastrointest. Endosc., 62 (5), $712-716$.

Song, H. J., Moon, J. S., Shim, K. N. (2016). Optimal bowel preparation for video capsule endoscopy. Gastroenterol. Res. Pract., 2016, 6802810.

Viazis, N., Sgouros, S., Papaxoinis, K., Vlachogiannakos, J., Bergele, C., Sklavos, P., Panani, A., Avgerinos, A. (2004). Bowel preparations increases the diagnostic yield of capsule endoscopy: A prospective, randomised, controlled trial. Gastrointest. Endosc., 60, 534-538.

Wei Wei, Zhi-Zheng Ge, Hong Lu, Yun-Jie Gao, Yun-Biao Hu, Shu-Dong Xiao (2008). Purgative bowel cleansing combined with Simethicone improves capsule endoscopy imaging. Amer. J. Gastroenterol., 103 (1), $77-82$.

Wu, S., Zhong, L., Zheng, P., Wang, Y. G., Ding, W. Q., Yu, Q., Hui, P. P., Chen, H. M., Gao, Y. J., Ge, Z. Z. (2019). Low-dose and same day use of polyethylene glycol improves image of video capsule endoscopy: A multicenter randomized clinical trial. J. Gastroenterol. Hepatol., 5 (4), 634-640.

Received 13 February 2020

Accepted in the final form 17 March 2020

\section{L POLIETILĒNGLIKOLA ŠK়̄DUMS KĀ TIEVĀS ZARNAS TİRĪŠANAS SHĒMAS PAMATLĪDZEKLIS PIRMS VIDEOKAPSULAS ENDOSKOPIJAS: STARPPOSMA ANALĪZE}

Kapsulas endoskopija (KE) ir principiāli jauna diagnostiskās endoskopijas metode. Tomēr šīs procedūras kvalitāti ietekmē vairāki faktori, t.sk. necaurlaidīgi škiidrumi, pārtikas atliekas utt. Pētījuma mērķis ir izvērtēt šobrīd vispopulārāko zarnas tīrǐšanas metodi un novērtēt iespējamos ietekmējošos faktorus. Analizēti $136 \mathrm{KE}$ gadījumi. Katrs pacients pirms KE tika gatavots ar 21 polietilēnglikola šķīdumu (PEG) dienu pirms manipulācijas. Katram pacientam aizpildīja speciālu anketu, kurā bija iekḷauti dažādi parametri (anamnēze, KE dati u.c.). No 136 KE gadījumiem $84(61,8 \%)$ bija sievietes un $52(38,2 \%)$ vīrieši. Tievās zarnas (TZ) tranzīta laiks 112 pacientiem variēja no 39 līdz 502 minūtēm, bet 24 gadījumos kapsula nesasniedza aklo zarnu. Zarnu tīrības pakāpe bija šāda: ḷoti laba - 30 (22,1\%) gadījumos, apmierinoša 97 (71,3\%), slikta - 9 (6,6\%). Tika novērota pozitīva korelācija starp TZ tīrības pakāpi un TZ tranzīta laiku (p =0,015). Respektīvi, jo ilgāks bija TZ tranzīts, jo sliktāka bija TZ tīrības pakāpe. Pētījumā iegūtie rezultāti pierāda, ka TZ tīrības kvalitāti ietekmē TZ tranzīta laiks. Salīdzinoši liels apmierinošas zarnu tīrības procents un salīdzinoši mazs ḷti labas zarnu tīrības procents, izmantojot TZ tīrǐšanas shēmā kā pamatlīdzekli 21 PEG pirms KE, norāda uz neatrisinātajiem jautājumiem zarnu sagatavošanā pirms KE. 